\title{
喉頭癌の両側頸部転移例に対する頸部郭清術の役割
}

\author{
大阪府立成人病センター耳咽喉科

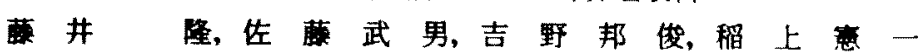 \\ 榣本典子, 上村裕和，長原昌萬 \\ 大阪船冥保险病院耳唡唯科 \\ 馬 谷 克 則
}

\section{TREATMENT OF BILATERAL NECK METASTASES IN LARYNGEAL CANCER}

TAKASHI FUJII, M.D., TAKEO SATO, M.D., KUNITOSHI YOSHINO, M.D.

KEN-ICHI INAKAMI, M.D., MICHIKO HASHIMOTO, M.D.

HIROKAZU UEMURA, M.D. and MASAMITSU NAGAHARA, M.D.

Department of Otolaryngology Head and Neck Surgery, The Center for Adulthood Diseases, Osaka

\section{KATSUNORI UMATANI, M.D.}

Department of Otolaryngology, Osaka Seamen's Insurance Hospital, Osaka

Laryngeal cancer is one of the most curable malignancies. One of the reasons is that most of them are in the early stage. However, the prognosis of advanced bilateral neck metastases is still poor. Based on loco-regional failure and cause of death, the effective procedure of neck dissection and the efficacy of postoperative irradiation were investigated retrospectively.

A total of 1022 patients with laryngeal squamous cell carcinoma were registered in our hospital between 1979 and 1991.58 of them $(5.7 \%)$ had bilateral neck metastases. Clinical N2c cases accounted for $52 \%(32 / 58)$. In the other patients, the metastatic nodes were revealed by elective neck dissection for a clinically negative neck. The $\mathrm{T}$ stages of the 58 cases were as follows; T2 in 14 cases. $\mathrm{T} 3$ in 22 and $\mathrm{T} 4$ in 22.

Forty-nine of the patients treated curatively by bilateral neck dissection were analyzed, 48 with total laryngectomy and 1 with partial laryngectomy. The remaining 9 patients were excluded because of radical irradiation in 3 , distant metastases found the diagnosis in 3 , unresectable recurrent neck metastases treated in other hospitals in 2 and no treatment because of severe myocardial infarction in 1.

Cumulative crude and cause-specific 5-year survival rates for the 49 patients were $32.2 \%$ and $52.2 \%$, respectively. Nineteen patients died of their disease ; 10 of them of an uncontrolled neck lesion.

From a comparison of the surgery alone group (28 cases) with a surgery plus irradiation group (21 cases) which consisted of preoperative irradiation in 2 and postoperative in 19, addition of irradiation may be effective for loco-regional control. Eight patients died of an uncontrolled neck lesion in the surgery alone group, while there were only 2 deaths in the postoperative irradiation group. Nevertheless there were no significant differences in survival: the cumulative crude and cause-specific 5-year survival rates in the surgery alone group were $34.4 \%$ and $56.2 \%$, respectively, 
while those in the surgery plus irradiation group were $28.6 \%$ and $46.3 \%$, respectively.

It is obvious that the procedure of neck dissection influenced the loco-regional control. Excluding the recurrence-free patients who died of intercurrent diseases within 2 years, recurrence in the ipsilateral neck was found in 1 of 12 patients with radical neck dissection (RND), in 1 of 3 with modified radical neck dissection (MRND), in 2 of 15 with lateral neck dissection (lateral ND) and in 9 of 11 with regional neck dissection (regional ND). Recurrence in the contralateral neck were found in none of 2 with RND, of 3 with MRND and of 20 with lateral ND, but in 6 of 16 with regional ND. These results suggest that regional ND was insufficient to accomplish loco-regional control in those patients and that lateral ND or MRND or RND may be required bilaterally.

Since 1986, all patients except 1 were treated by more extensive maneuvers than lateral ND bilaterally, so that loco-regional recurrence was found in only 1 case, in spite of the fact that the surgery alone group accounted for $73 \%(19 / 26)$. Cumulative crude and cause-specific 5-year survival rates for the patients prior to 1985 (23 cases) were $26.1 \%$ and $32.6 \%$, respectively, while those for the patients since 1986 ( 26 cases) were $38.5 \%$ and $76.9 \%$, respectively. There was no significant difference $(p=0.73)$ in cumulative crude 5 -year survival rates between the 2 groups, but the difference in their cause-specific 5-year survival rates was statistically highly significant $(\mathrm{p}=0.0032)$.

It was concluded that lateral ND, MRND or RND should be required bilaterally for the patients with bilateral neck metastases and that addition of irradiation is not always indispensable for patients treated by curative neck dissection, such as lateral ND, MRND or RND.

Key words : 搌頭瘦, 顠部転移, laryngeal cancer, neck metastasis, survival

A $97-0662-60389$

\section{はじめに}

㶼頭癌は他の頭頸部禹に比べ早期禹の占める割合が

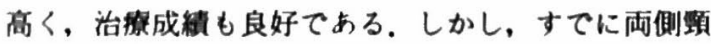
部転移を来した症例は, loco- regionalに最も広範曲 に進展した進行㾔てあり，その予後は决して良いとは 考关られない。このような症例に対しては，顒部部清 術が必湏と考えられる. 顒部の再発率および死因を分 析することにより，有奻な買部郭清術式，術後照射の 有用性，また全身治㩲の必要性について検討し，治療 成績向上の可能性について考察した。

研究対象と治法

1979〜1991年の13年間に当科で登録された喉頭癌症 例1022例のうち, 両側䫅部転移例は 58 例 (5.7\%)であっ た。このうち 4 例（根治照射 3 例・無治撩 1 例）は触 䛦による臨床的跈断に基つくく症例てあるが, 残る54例 は全例両側䫫部部清術による摘出標本から病理組織学 的に確認された $(\mathrm{pN} 2 \mathrm{c})$ 症例であった. 原発部位別内 訳は, 声門瘦 7 例・声門上癌51例（弓ち混合型 8 例）
てあり, 男女比は, $50: 8$, 平均年秢は 64.9 歳 (45 88 歳)であった。臨床 TN 病期分類は表 1 のごとく, clinical N2c 症例は $52 \%(32 / 58)$ であり, 残りは一側また は両側の予防的顓部部清術により $\mathrm{pN} 2 \mathrm{c}$ となった症例 てあった。 なお, 対象症例の中に $\mathrm{N} 3$ 症例が 1 例 ( $\mathrm{T} 3$ N3）みられたが，術前より両側頸部転移が認められた ため T3N2c に再分類した. 手術例54例のうち非根治 例は 5 例であったが, その理由は搒断時の遠隔転移 ( 3

表 1 両側頸部転移例の臨床 TN 病期分類 (UICC, 1987)

\begin{tabular}{crrrr}
\hline N病期 & T2 & T3 & T4 & 計 \\
\hline N0 & 2 & 3 & 6 & 11 \\
N1 & 3 & 4 & 1 & 8 \\
N2a & 2 & 1 & 1 & 4 \\
N2b & 0 & 2 & 1 & 3 \\
N2c & 7 & 12 & 12 & 32 \\
\hline 計 & 14 & 22 & 22 & 58 \\
\hline
\end{tabular}


例) と他院にて手術後の再発部位が切除不可能 (2 例) てあったためてある.

根治手術店例49例の原発巣に対する治療は, 水平部 分切除術 1 例を除き，全例喉頭全摘出術てあった. 頸

表 2 頭部に対する治療法別區床病期N分類

\begin{tabular}{ccccccc}
\hline 治 虔法 & N0 & N1 & N2a & N2b & N2c & 計 \\
\hline 手街単独 & 5 & 4 & 3 & 2 & 14 & 28 \\
照射併用 & 5 & 3 & 1 & 1 & 11 & 21 \\
\hline
\end{tabular}

部に対する治療は, 頸部郭清術のみ(以下, 手術単独 群）28例, 照射併用 (以下, 照射併用群) 21例であっ た.これらの治療法の選択は, 主治医の判断に基づく ものであったが, 臨床病期 $\mathrm{N}$ 分類の分布に差は認めら れなかった(表 2 ).

影部部清術式の分類は, the Academy's Committee for Head and Neck Surgery and Oncology $の$ official report(1991年)"に準じて行った(図 1 )。おおむね上・ 中・下内深顠リンパ節群に相当する II・III・IV領域を

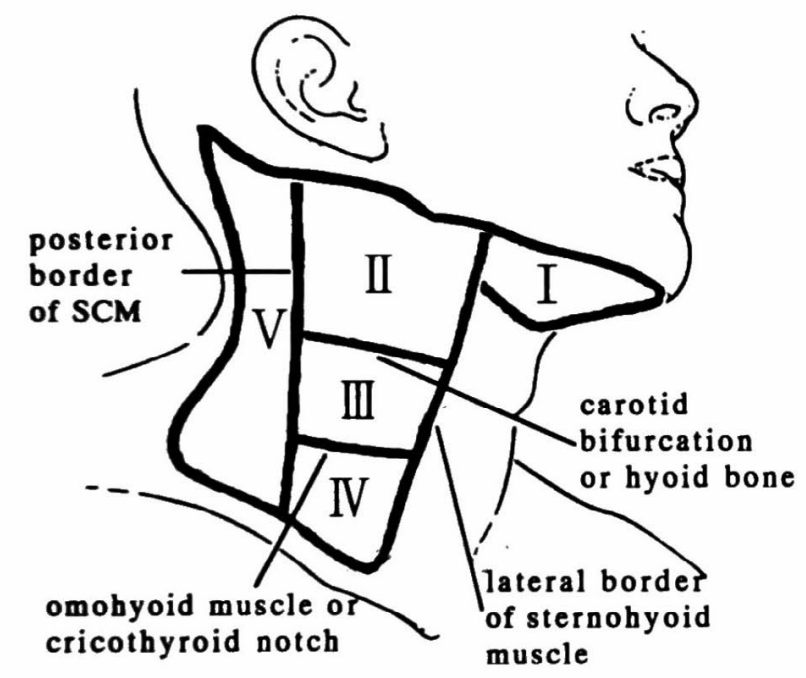

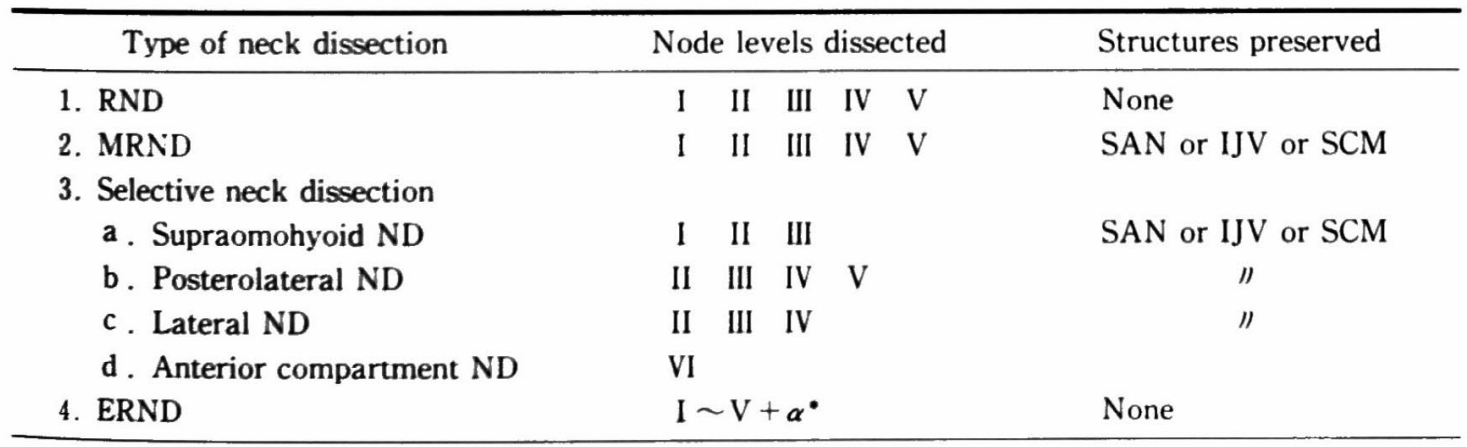

RND : Radical neck dissection

MRND : Modified radical neck dissection

ERND : Extended radical neck dissection

SAN : spinal accessory nerve,

IJV : internal jugular vein,

SCM : sternocleid mastoideus muscle,

$\alpha^{*}$ : parapharyngeal, superior mediastinal, paratracheal lymphnode

図 1 顒部郭清術の分類

(The Academy's Committee for Head and Neck

Surgery and Oncology の official reportより) 


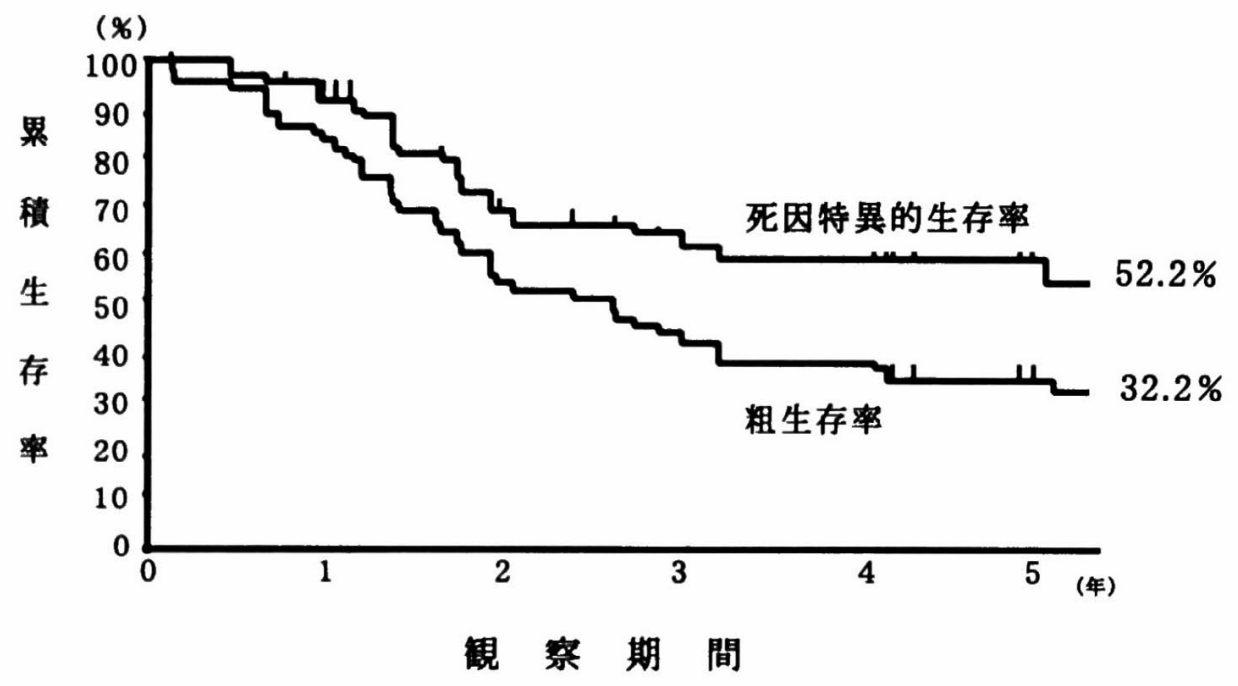

図 2 根治手術例49例の治療成績

表 3 根治手術例の死因

\begin{tabular}{cccc}
\hline 死 因 & & 症例数 & \\
\hline 原病死 & & 19 & \\
& $\mathrm{~T}+\mathrm{N}$ & & 1 \\
& $\mathrm{~T}+\mathrm{M}$ & & 1 \\
& $\mathrm{~N}$ & & 5 \\
& $\mathrm{~N}+\mathrm{M}$ & & 5 \\
他因死 & $\mathrm{M}$ & & 7 \\
& 他瘠死 & 14 & \\
\hline 計 & & 33 & 6 \\
\hline
\end{tabular}

郭清する lateral neck dissection（以下，lateral ND） が、喉頭輁では用いられることが多いためこれを基準 とした。郭溜範囲がそれよりさらに狭い場合を regional neck dissection (以下, regional ND) とし た.

照射併用群21例の照射線量は, 術前照射 2 例が $20 \mathrm{~Gy}$, 術後照射19例は, 1 例の $60 \mathrm{~Gy}$ を除き全例 $50 \mathrm{~Gy}$ であり，照射野は全顒部であった。

また, 手術単独群28例のうち, 7 例に術後約 1 年間 全身補助療法の追加が行われていた。 その内訳は, 化 学療法 4 例（テガフール・ウラシル内服 3 例, 硫酸ぺ プロマイシン筋肉注射 1 例), 免疫療法 (OK-432 皮下 注射) 1 例, 化学撙法と免疫療法の併用 2 例 (テガフー ル・ウラシル内服とOK-432 皮下注射 1 例, カルモフー
ル内服とシソフィラン筋肉注射 1 例) であった. 照射 併用群では, 全身補助㫱法の追加は全く行われていな かった.

なお, 全例, 死亡まであるいは最短 4 年間のfollowupが行われていた.

生存率の算出には, Kaplan-Meier 法による累積生 存率を用い, 検定法は logrank test と generalized Wilcoxon test を用いた. また, 2 群間の比率の検定に は $\chi^{2}$ 検定を用いた。

\section{結果}

根治手術例 49 例の治療成績（図 2 ）は，5 年粗生存 率が $32.2 \%$, 死因を原病死に限った死因特異的 5 年生 存率が52.2\%であった，死因分析（表 3 ）で, 原病 死は19例にみられ，原発巣非制御死 $(T+N$ 死と $T+$ $M$ 死) が 2 例, 頸部非制御死 $(\mathrm{N}$ 死と $\mathrm{N}+\mathrm{M}$ 死) が10 例を占め, 遠隔転移死 ( $\mathrm{M}$ 死) も 7 例を占めた。 また， 他癌死は 6 例にみられた。

手術単独例（28例）と照射併用例（21例）を比較す ると, 5 年粗生存率は手術単独群 $34.4 \%$ ・照射併用群 $28.6 \%(\mathrm{p}=0.49)$, 死因特異的 5 年生存率は手術単独 群 $56.2 \%$ •照射併用群 $46.3 \% （ \mathrm{p}=0.25 ）$ と, いずれも 両群間に有意差は認められなかった(図 3)。しかしな がら, 死因について比較すると(表 4), 手術単独群の 原病死 9 例のうち頸部非制御死が 8 例 (89\%) であつ たのに対し，照射併用群の原病死10例のうち顓部非制 


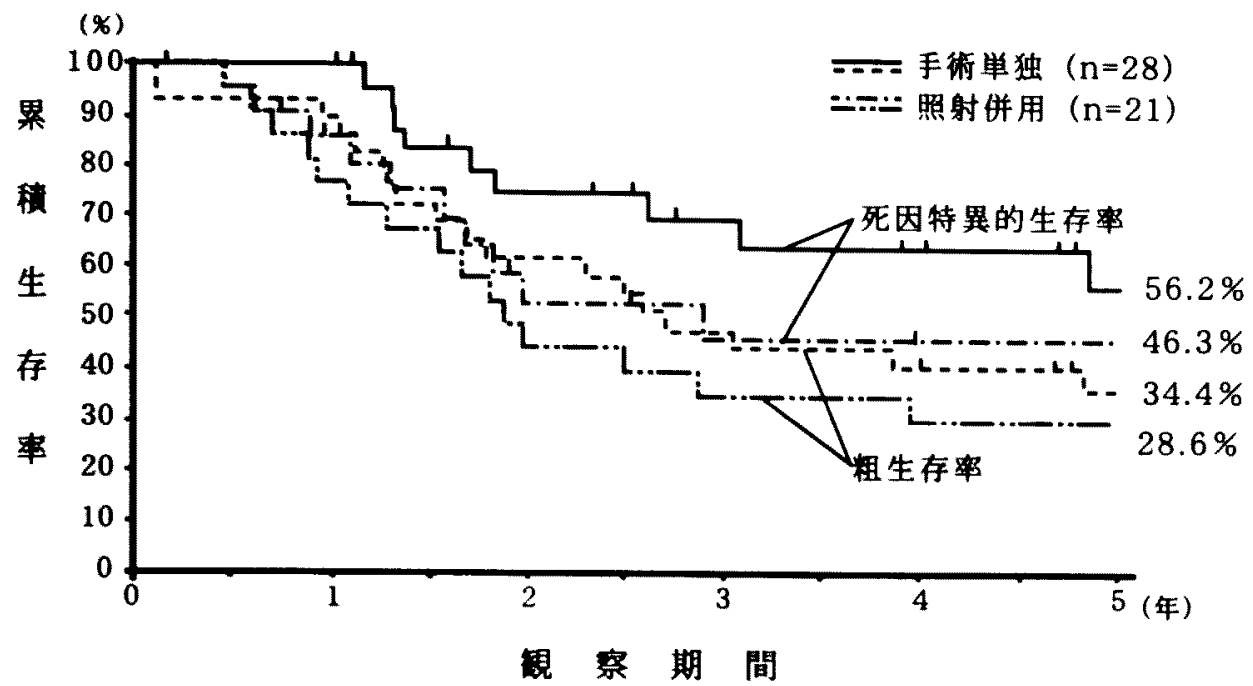

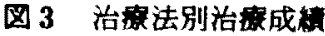

话 4 治慗法別の死因

\begin{tabular}{|c|c|c|c|c|c|c|}
\hline \multirow{2}{*}{ 死 因 } & & \multicolumn{5}{|c|}{ 治 方 } \\
\hline & & \multicolumn{2}{|c|}{ 手街単役 } & \multicolumn{3}{|c|}{ 照射併用 } \\
\hline 原病死 & & 9 & & 1 & & \\
\hline & $\mathbf{T}+\mathbf{N}$ & & 0 & & & 1 \\
\hline & $\mathbf{T}+\mathbf{M}$ & & 0 & & & 1 \\
\hline & $N$ & & 4 & & & 1 \\
\hline & $\mathrm{N}+\mathrm{M}$ & & 4 & & & 1 \\
\hline & $\mathbf{M}$ & & 1 & & & 6 \\
\hline 他因死 & & 9 & & & 5 & \\
\hline 計 & & 18 & & 1 & & \\
\hline
\end{tabular}

死は 2 例 (20\%)のみて、М死が6例を占めていた。

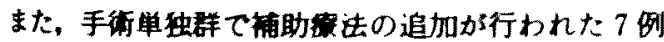

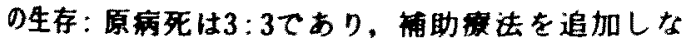
かった21間の7:6との間に全く差は辇められなかった (表5).

更部に対する治寝法の年次別推移では，1989年以降 注标とんど全例手術単独となっていた（図 4)。照射併 用群ては21例のうち生存例が6例にみられたが，年次

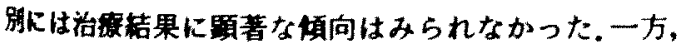
手衙単独群では，1985年以前（9例）は原病死が 7 例 を占め生存例は1例のみでったが，1986年以降（19

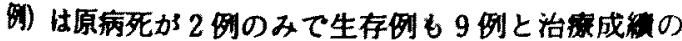
向上がみられた。

そこで，その原因が顒部部消の術式に起因するのか
表 5 補助㒉法別の治度結果

\begin{tabular}{|c|c|c|c|c|c|c|c|c|}
\hline 補 & 助 & 㞠 & 法 & 生 & 存 & 他因死 & 原病死 & 計 \\
\hline な & & & L & & 7 & 8 & 6 & 21 \\
\hline 化 & 学 & 療 & 法 & & 1 & 1 & 2 & 4 \\
\hline 免 & 疫 & 类 & 法 & & 1 & 0 & 0 & 1 \\
\hline \multicolumn{4}{|c|}{ 化学暴法十免度㞠法 } & & 1 & 0 & 1 & 2 \\
\hline \multicolumn{4}{|c|}{ 計 } & 1 & 0 & 9 & 9 & 28 \\
\hline
\end{tabular}

否かを検討するために，1985年以前と1986年以降の影 部部清術式と再発頻度を比較した。なお，顽部の制御 を明確にするため，䃇部再発が認められすに2 年以内 に死亡した 8 例は除外して模討した（表 6)，1986年以 降估 1 例を除き全例に乘侧とも lateral ND以上が行 われており，额部再発は患側に1例認められたのみて あった．1985年以前の患側ては、約半数に行われた regional ND の $82 \%(9 / 11)$ に再発がみられたが, lat. eral ND以上では25\%（3/12）のみてあった，健側て も, lateral NDが行われた症例に再発はみられなかっ た。 1985年以前の症例 (23例) と1986年以降の症例 (26 例）を比校すると，5年粗生存率では各々 $26.1 \%$, $38.5 \%(p=0.73)$ と有意な向上は認められなかった が，死因特異的 5 年生存率ては $32.6 \%$ から $76.9 \%$ へ （ $p=0.0032 ）$ と有意な向上が証め5れた（図 5)，死因 分析（表 7$) て も ， 1986$ 年以降は手術单独例が73\%(19/ 26）を占めるにもかか力らず，原病死は 4 例（22\%） て，そのうち頸部非制御死は1例のみであり，1985年 


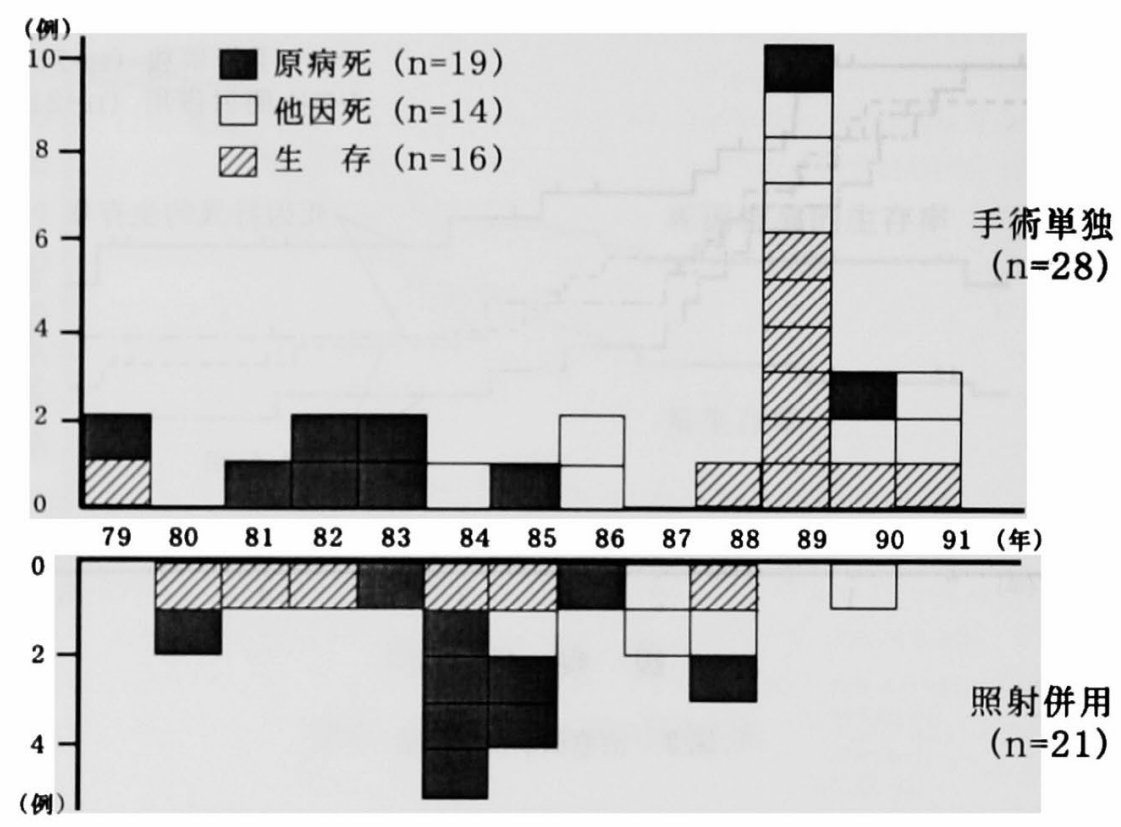

图 4 治㞠法の年次推移と治療結果

表 6 年代別顠部郭清術式の相連による䫫部再発の頻度

\begin{tabular}{|c|c|c|c|c|c|c|}
\hline \multirow{2}{*}{ 垶 清 術 式 } & \multicolumn{2}{|c|}{ 患 } & 側 & \multicolumn{2}{|c|}{ 健 } & 側 \\
\hline & '79 '85 & '86 '91 & 計 & '79 '85 & '86〜'91 & 計 \\
\hline RND & $1 / 1$ & $0 / 11$ & $1 / 12$ & & $0 / 2$ & $0 / 2$ \\
\hline MRND & $0 / 1$ & $1 / 2$ & $1 / 3$ & & $0 / 3$ & $0 / 3$ \\
\hline lateral ND & $2 / 10$ & $0 / 5$ & $2 / 15$ & $0 / 8$ & $0 / 12$ & $0 / 20$ \\
\hline regional ND & $9 / 11$ & & $9 / 11$ & $6 / 15$ & $0 / 1$ & $6 / 16$ \\
\hline 計 & $12 / 23$ & $1 / 18$ & $13 / 41$ & $6 / 23$ & $0 / 18$ & $6 / 41$ \\
\hline
\end{tabular}

RND : Radical neck dissection MRND : Modified radical neck dissection

lateral $\mathrm{ND}$ : lateral neck dissection regional $\mathrm{ND}$ : regional neck dissection

以前の原病死15例 $(65 \%) \cdot$ 顒部非制御死 9 例に比べ, 影著な減少を訆めた。

\section{考察}

喉頭癌の予後に影響を及ぽす因子の一つに頸部リン パ節転移があり，転移リンパ節の個数・節外進展の有 無が予後と有意に相関するとの報告2)もある。すてに 両側㹕部転移を来した症例は, loco-regionalに最も広 範囲に進展した進行㾔であり,われわれの結果ても， 根治手術例 49 例の 5 年累積粗生存率が $32.2 \%$ ・死因特 異的 5 年生存率が $52.2 \%$ に過ぎなかった。これら両側 頸部転移例の治療成績向上のためには, loco-regional
の制御率向上が不可欠であり, 頸部郭清術の方法と照 射併用の意義についての検討が重要であると考えられ る.なお今回, 頸部郭清術の分類を, the Academy's Committee for Head and Neck Surgery and On. cology の official report (1991年) ${ }^{1}$ に準じて行った主 な理由は, 各境界, 特に II IIIIV領域の外側（後方）の 境界がより明確に規定されており，喉頭癌の場合によ く用いられる lateral ND を基準とした郭清範囲の比 較が容易であると考えたためであり，また今後この統 一された分類が普及することが予想されるためでもあ る.

喉㩆瘁の中で声門ト癌はリンパ節転移を来しやす 


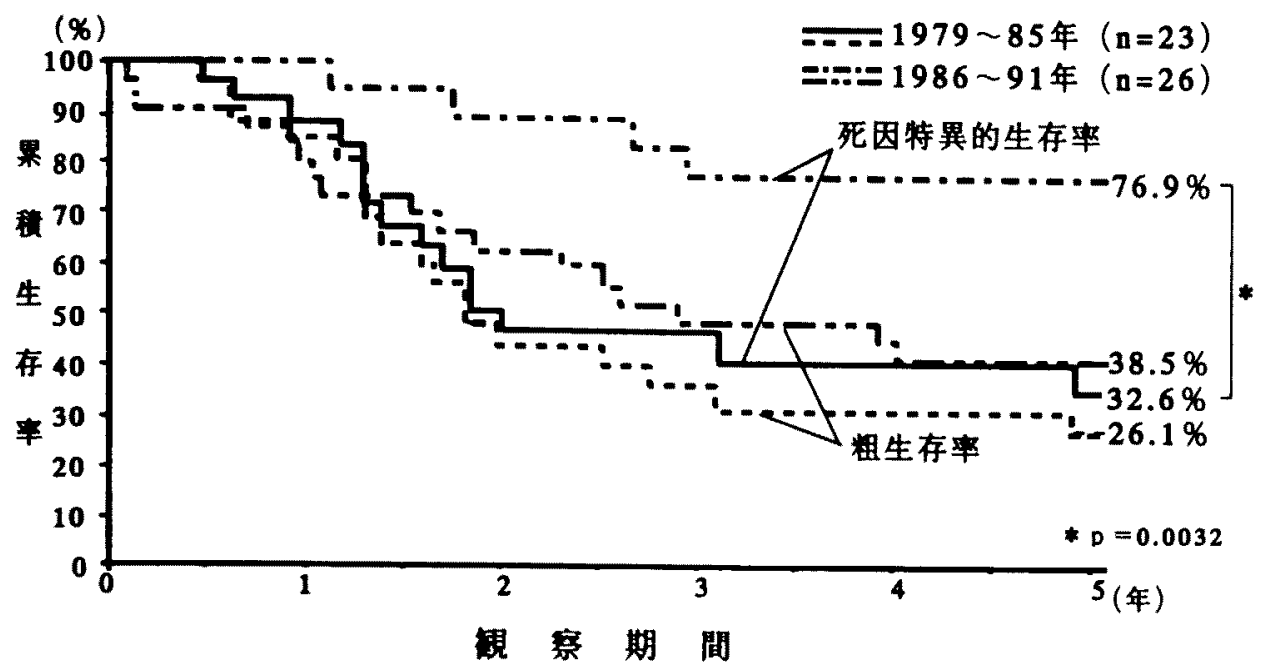

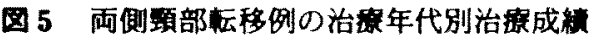

表 7 治重時期別の死因

\begin{tabular}{cccccc}
\hline \multirow{2}{*}{ 死因 } & & \multicolumn{3}{c}{ 治 } & 時 期 \\
\cline { 3 - 5 } & & $1979 \sim 85$ 年 & $1986 \sim 91$ 年 \\
\hline 原病死 & & 15 & & 4 & \\
& $\mathrm{~T}+\mathrm{N}$ & & 1 & & 0 \\
& $\mathrm{~T}+\mathrm{M}$ & & 1 & & 0 \\
& $\mathrm{~N}$ & & 5 & & 0 \\
& $\mathrm{~N}+\mathrm{M}$ & & 4 & & 1 \\
& $\mathrm{M}$ & & 4 & & 3 \\
他因死 & & 2 & & 12 & \\
& 他盘死 & & 1 & & 5 \\
\hline 計 & & 17 & & 16 & \\
\hline
\end{tabular}

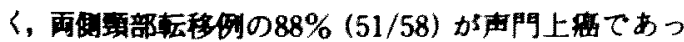
た。そのため，声門上㖦に対しては手術例全例に車側

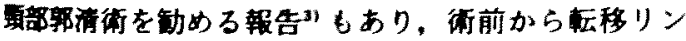

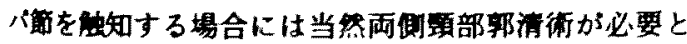
なる. 今回の結果から，顠部部消術の術式としては，

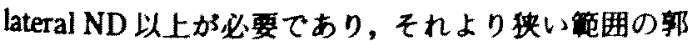
滴街式 (regional ND) では㖣部再発の危険性が高いこ とが推察された。しかしながら，頭部の制御のために は必ずしも根本的䫓部部清術（RND）を行う必要はな く，街前に蛞する较移リンパ筹の部位や状況に応し

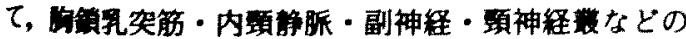
一部または全部を保存した lateral ND で制御が可能 であると思われた。 とくに，傮側の顒部部消術や予防
的頙部部清術としてここれらを保存した lateral NDを 行った症例に 1 例も䫓部再発がみられなかったことよ り，諸家の報告(15) と同様に機能保存と根治性の両立は 可能てあると考えられた。

照射併用の意義について, Byers ら ${ }^{61}$ は併用療法の 有奻性を報告しているが，手術単独例と比較して顠部 制御率・生存率に差を認めないという報告33417日)も多 い. Bocca" は, 巨大な固着した頭部轱移例に対する術 前照射と明らかな節外進展例に対する術後照射以外に は，根治手術例には照射併用を勒めないと報告してい る。われわれの結果からは，1985年以前には局所麻酔 下ての手術や的々の理由による手術時間の制限などの ため部海筑囲の狭い症例が多かったため，手術单独群 の䫫部制御率が低く、照射併用により頚部制御率の向 上がみられたと考えられだ。しかし，遠隔転移が高率

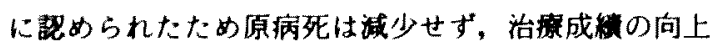
はみられなかった。 Suárez ら”は声門上舟で, Jesse

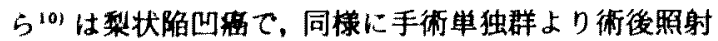

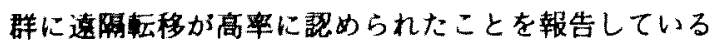
が，その理由については言及しておらず，遠隔転移と 術後照射の因果関倸に関しては，われわれもその理由 を明確に示すことはできない。一方，1986年以降はほ とんど全例に両側 lateral ND 以上の籍用の䫫部部清 術が行われるようになり、䫫部非制御死は 1 例のみと なった。したがって，根治手術として耐側の lateral ND 以上の籍囲の新部部消術が施行されている症例に 対しては術後照射併用の必要性はないと考えられる。 
なんらかの理由により，そのような䤄部郭清術が不可 能な場合にのみ, 頸部再発率の低下を目的とした術後 照射の追加の適応があるのではないかと思われる，対 象症例の中に $\mathrm{N} 3$ 症例は 1 例しか含まれていなかった ため、N3 症例に対する照射併用の必要性扔よび効果 については検討し得なかった。

Loco-regional の制御が可能になると, 残る問題は 遠同転移であが、このような症例に対する遠隔転移 予防に有効な治撩法に関する報告は見あたらない。わ れわれの結果からは, 化学撩法や免疫撩法等の補助撩 法を追加した群と追加しなかった群との間に治撩結果 の差を証めることはできなかたが, 症例数も少なく 背量因子を䦌別化しているわけでないため結論付け ることはてきない，今後, このような両側頉部転移例 に対して、両側 lateral ND 以上の䫓部部清術のみを 行って治撩法を統一し, 補助療法追加の有無による randomized controlled trial を行えぼ，全身治療の効 果についての結論が得られるものと思われる.

\section{まとめ}

1. 1979 1991年の喉頭癌1022例中, 両側頭部転移 例は 58 例 (5.7\%) でり, そのうち根治手術を施行し た 49 例の 5 年累積粗生存率は $32.2 \%$, 死因特異的 5 年 生存率は $52.2 \%$ でった。

2. 䫫部郭清術の郭清簀囲の狭い症例に頚部非制御 例が多く、これらの症例では術後照射併用による頍部 制御率の向上かみられたが，高平にみられた遠隔転移 のため原病死は減少せず，照射併用による治撩成績の 向上はみられなかった。

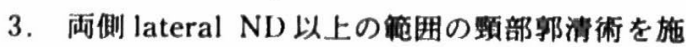
行することにより, 手術単独ても頻部非制御例は影著 に減少し、治撰成績の向上に結び付いていた。

\section{考考文哭}

1) Robbins KT, Medina JE, Wolf GT, Levine PA, Sessions RB, et al: Standardizing neck dissection terminology : official report of the Academy's Com. mittee for Head and Neck Surgery and Oncology. Arch Otolaryngol Head Neck Surg 117 : 601-605. 1991.
2) De Guzmán RB, Martorell MA, Basterra J, Armengot M, Alvarez-Valdés R, et al : Prognostic value of histopathological parameters in 51 suprag. lottic squamous cell carcinomas. Laryngoscope 103: 538-540, 1993.

3) Weber PC, Johnson JT, Myers EN : The impact of bilateral neck dissection on pattern of recurrence and survival in supraglottic carcinoma. Arch Otolaryngol Head Neck Surg 120: 703-706, 1994.

4) De Santo LW, Holt JJ, Beahrs OH, O'Falon WM: Neck dissection: is it worthwhile? Laryngoscope 92: 502-509, 1982.

5) Deutsh EC, Skolnik EM, Friedman M, Hill JH, Sharer $\mathrm{K}$ : The conservation neck dissection. Laryngoscope 95: 561-565, 1985.

6) Byers RM, Wolf PF, Ballantyne AJ : Rationale for elective neck dissection for cancer of the larynx. Head Neck Surg 10:160-167, 1988.

7) Suárez C, Llorente JL, Nuñez F, Diaz C, Gomez J: Neck dissection with or without postoperative radiotherapy in supraglottic carcinomas. Otolaryngol Head Neck Surg 109: 3-9, 1993.

8) Schuller DE, McCGuirt WF, Krause CJ, McCabe $B F$, Pflug BK : Increased survival with surgery alone vs. combined therapy. Laryngoscope 89 : 582-594, 1979.

9) Bocca E : Surgical management of supraglottic cancer and its lymph node metastases in a conserva. tive perspective. Ann Otol Rhinol Laryngol 100: 261-267, 1991.

10) Jesse $R H$, Lindberg RD: The efficacy of combining radiation therapy with a surgical procedure in patients with cervical metastasis from squamous cancer of the oropharynx and hypopharynx. Cancer 35 : 1163-1166, 1975.

本論文の要旨は, 第96回日本耳鼻咽喉科学会総会 (1995年 5 月,千葉) において発表した。

（1995年12月13日受稿 1996 年 2 月 1 日受理）

別刷請求先 $\bar{\top} 537$ 大阪市東成区中道1-3-3

大阪府立成人病センター耳姐咽喉科 藤井 隆 


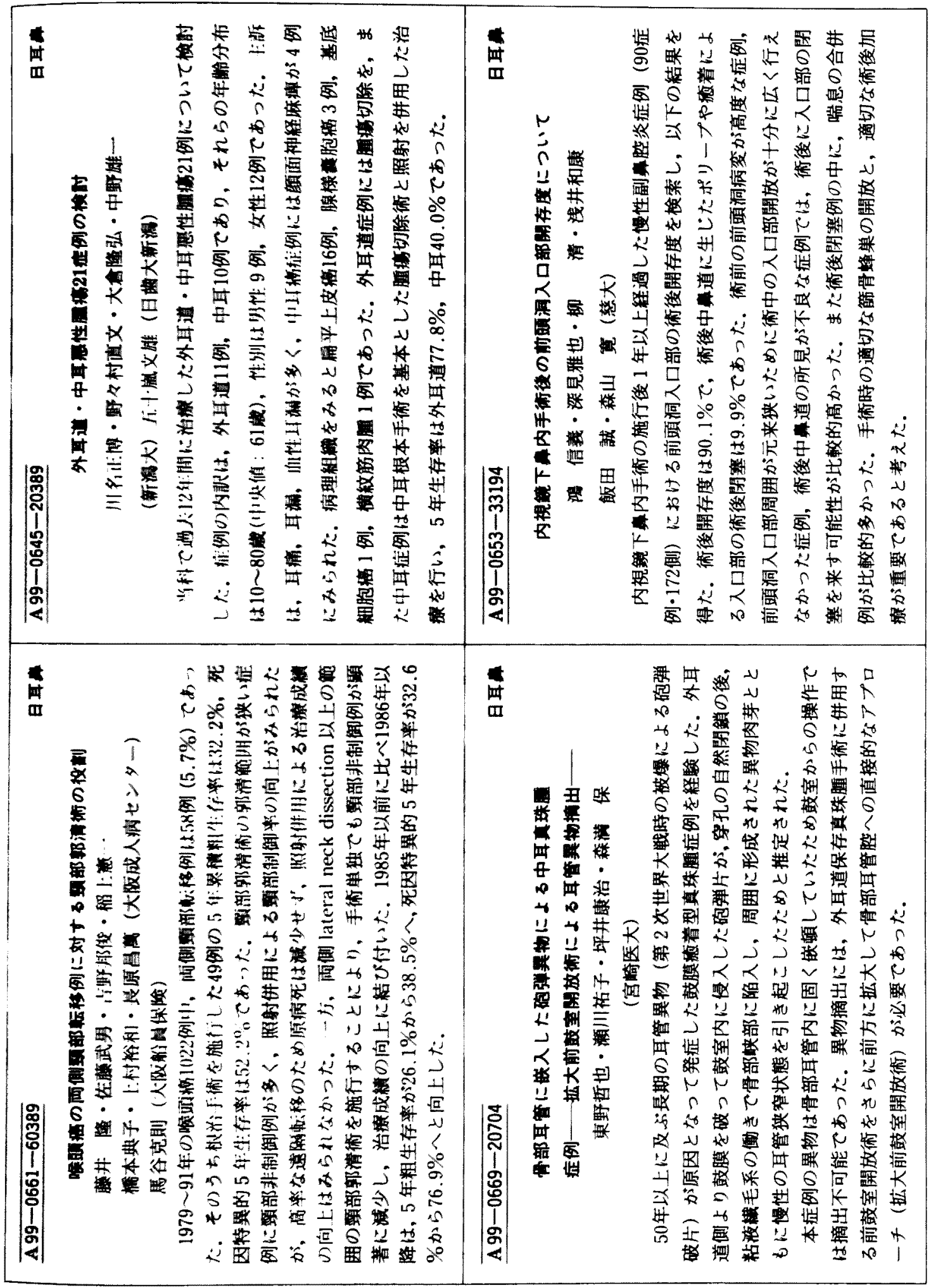

